\title{
Biodegradation of atrazine and ligninolytic enzyme production by basidiomycete strains
}

\author{
Caroline Henn ${ }^{1 *}\left(\mathbb{D}\right.$, Diego Alves Monteiro ${ }^{2}$, Mauricio Boscolo ${ }^{2 \dagger}$, Roberto da Silva $^{2}$ and Eleni Gomes ${ }^{2 \dagger}$
}

\begin{abstract}
Background: Atrazine is one of the most widespread chlorinated herbicides, leaving large bulks in soils and groundwater. The biodegradation of atrazine by bacteria is well described, but many aspects of the fungal metabolism of this compound remain unclear. Thus, we investigated the toxicity and degradation of atrazine by 13 rainforest basidiomycete strains.
\end{abstract}

Results: In liquid medium, Pluteus cubensis SXS320, Gloelophyllum striatum MCA7, and Agaricales MCA17 removed 30,37 , and 38\%, respectively, of initial $25 \mathrm{mg} \mathrm{L}^{-1}$ of the herbicide within 20 days. Deficiency of nitrogen drove atrazine degradation by Pluteus cubensis SXS320; this strain removed 30\% of atrazine within 20 days in a culture medium with $2.5 \mathrm{mM}$ of $\mathrm{N}$, raising three metabolites; in a medium with $25 \mathrm{mM}$ of $\mathrm{N}$, only $21 \%$ of initial atrazine were removed after 40 days, and two metabolites appeared in culture extracts. This is the first report of such different outcomes linked to nitrogen availability during the biodegradation of atrazine by basidiomycetes. The herbicide also induced synthesis and secretion of extracellular laccases by Datronia caperata MCA5, Pycnoporus sanguineus MCA16, and Polyporus tenuiculus MCA11. Laccase levels produced by of P. tenuiculus MCA11 were 13.3fold superior in the contaminated medium than in control; the possible role of this enzyme on atrazine biodegradation was evaluated, considering the strong induction and the removal of 13.9\% of the herbicide in vivo. Although $88 \%$ of initial laccase activity remained after $6 \mathrm{~h}$, no evidence of in vitro degradation was observed, even though ABTS was present as mediator.

Conclusions: This study revealed a high potential for atrazine biodegradation among tropical basidiomycete strains. Further investigations, focusing on less explored ligninolytic enzymes and cell-bound mechanisms, could enlighten key aspects of the atrazine fungal metabolism and the role of the nitrogen in the process.

Keywords: Fungal metabolism, Biodegradation, Laccase, Organochlorinated, Rainforest fungi, Basidiomycete, Co-metabolism

\footnotetext{
* Correspondence: carol_henn@yahoo.com.br

${ }^{\dagger}$ Caroline Henn, Mauricio Boscolo and Eleni Gomes contributed equally to this work.

${ }^{1}$ ITAIPU Binacional, Divisão de Reservatório, Avenida Tancredo Neves, 6731,

Foz do Iguaçu, PR 85866-900, Brasil

Full list of author information is available at the end of the article
}

(c) The Author(s). 2020 Open Access This article is licensed under a Creative Commons Attribution 4.0 International License, which permits use, sharing, adaptation, distribution and reproduction in any medium or format, as long as you give appropriate credit to the original author(s) and the source, provide a link to the Creative Commons licence, and indicate if changes were made. The images or other third party material in this article are included in the article's Creative Commons licence, unless indicated otherwise in a credit line to the material. If material is not included in the article's Creative Commons licence and your intended use is not permitted by statutory regulation or exceeds the permitted use, you will need to obtain permission directly from the copyright holder. To view a copy of this licence, visit http://creativecommons.org/licenses/by/4.0/ The Creative Commons Public Domain Dedication waiver (http://creativecommons.org/publicdomain/zero/1.0/) applies to the data made available in this article, unless otherwise stated in a credit line to the data. 


\section{Background}

Agricultural production is strongly dependent on agrochemicals. Atrazine (2-chloro-4-ethylamino-6-isopropylamino)-1,3,5-triazine) is the second most employed herbicide worldwide, used to control broadleaf weeds in sugarcane and maize plantations. It has considerable persistence, with a half-life of around 41-231 days, and high solubility and mobility in soils, raising concerns about groundwater contamination. As a result, atrazine may enter the food chain, affecting biodiversity and human health [1-3]. Atrazine belongs to the chemical class of chlorinated triazines, and is formed by a heterocyclic aromatic ring alternating carbon and nitrogen atoms, besides chlorine substituent. Like other halogenated aromatic compounds, atrazine and its dealkylated and deaminated metabolites are toxic, carcinogenic and endocrine disruptors $[3,4]$.

Once lignin polyphenolic structure presents similarities with many aromatic pollutants, microbial ligninolytic systems have been extensively studied in the last years, searching for potential tools for bioremediation of contaminated sites and for a better understanding of the environmental fate of toxic compounds [5, 6]. Recent proteomic approaches concluded that wood decay, itself, is a source of toxic phenolic derivatives and reactive oxygen species; thus, ligninolytic and stress response enzymes are expressed simultaneously [7]. White-rot fungi are the main producers of non-specific oxidases that can act upon a wide range of substrates. Laccases (Lac EC 1.10.3.2), lignin peroxidases (LiP; EC 1.11.1.14) and manganese peroxidases (MnP; EC 1.11.1.13) are responsible for the degradation of the most recalcitrant molecule in nature [8]. Thus, the co-metabolic biodegradation of pesticides, PAHs (polycyclic aromatic hydrocarbons), polychlorinated phenols, polymers, dioxins, pesticides, and dyes by ligninases have been subject of intense research [9-13].

A complete catabolic pathway for atrazine biodegradation was already described for bacteria (e.g., Pseudomonas strain ADP). The plasmidial genes atzA, atzB, and atzC encode hydrolytic enzymes, responsible for atrazine mineralization [14]. Conversely, fungal biodegradation is based on oxidative-hydrolytic mechanisms and until now, the metabolic routes identified are more diverse. Fungi usually modify the molecule by sequentially removing aromatic ring substituents, with dealkylation as first step $[15,16]$. The resulting metabolites, such as deethylatrazine (DEA), deisopropylatrazine (DIA), deethyldeisopropylatrazine (DEA-DIA), and hydroxyatrazine (HA) still retain the aromatic ring $[16,17]$. The degradation of atrazine derivatives DIA and DEA by a fungal strain (Pleurotus ostreatus INCQS 40310) was only recently described [4].

Despite the limitations imposed by the incomplete atrazine biodegradation by basidiomycetes in pure cultures, studies applying purified ligninolytic enzymes under controlled conditions, or adopting co-cultures involving soil bacteria and deuteromycetes, have been successful in achieving complete dissipation of atrazine and detoxification of contaminated substrates [4, 18, 19]. White-rot fungi bioremediation approaches also present the advantage of being low cost processes, once fungal species are usually not fastidious; being mainly saprophytes, their growth can be easily supported by the organic residues, in laboratory culture conditions or in the field [20]. Among the few nutritional exigencies to observe, nitrogen availability plays a central role; when ligninolytic enzymes are responsible for the biodegradation, it may be necessary to establish nitrogen-starving conditions. On the other side, cell bound mechanisms are favored by nutrient rich medium, supporting an extensive biomass development. In this sense, a previous exploration of metabolic profile of indigenous fungal strains is critical during the prospection of species for this purpose [21-23].

The current knowledge about fungal biodegradation of xenobiotics and the role of ligninolytic enzymes is based on the findings for a few well studied basidiomycete strains, mainly Pleurotus pulmonarius, Phanerochaete chrysosporium, Lentinus spp., Pleurotus spp. and Trametes spp. [5, 16, 20, 21]. Some of the most recent estimates about fungal biodiversity suggest the existence of 2.2 to 3.8 million species, being only 120,000 currently described [24]. Therefore, a wide frontier in microbial diversity - and its biotechnological potential - remains unexplored. Tropical rainforests in South America are considered biodiversity hotspots, and account for much of this gap. In this work, we screened fungal strains, isolated from tropical rainforest fragments, for their capacity of growing in the presence of atrazine and metabolizing it. We also observed the profile of secondary metabolites arising from atrazine degradation under different culture conditions, while searching for a possible role of ligninolytic enzymes and nitrogen availability in the process.

\section{Results}

Although all microorganisms studied here were sensitive to atrazine to some degree, all could grow. Inhibition rates were very similar for the two atrazine concentrations (6.25 $\mathrm{g} \mathrm{L}^{-1}$ and $10 \mathrm{~g} \mathrm{~L}^{-1}$, Table 1$)$, and always distinct from the control; except for P. tenuiculus MCA11, for which a difference $(p \leq 0.05)$ was observed between distinct atrazine levels. At $6.25 \mathrm{~g} \mathrm{~L}^{-1}$, we found minor inhibitory effect for Polyporus tenuiculus MCA9 (42\%) and Pluteus cubensis SXS320 (44\%); conversely, the most affected strains were Polyporus sp. MCA128 and Datronia stereoides MCA167, which showed inhibition of 72 and $73 \%$, respectively. The fungal mycelium of some strains was much denser in the contaminated medium 
Table 1 Growth inhibition of fungal strains in PDA medium containing atrazine. M.D.: mycelium density; weak (1); medium (2); high (3). Superscript lowercase letters (a, b, and c) refers to statistically distinct groups

\begin{tabular}{|c|c|c|c|c|c|c|c|c|}
\hline \multirow[t]{2}{*}{ Strain } & \multicolumn{2}{|l|}{ Control } & \multicolumn{3}{|l|}{$6.25 \mathrm{mg} \mathrm{L}^{-1}$} & \multicolumn{3}{|l|}{$10.0 \mathrm{mg} \mathrm{L}^{-1}$} \\
\hline & $\begin{array}{l}\text { Diameter growth }(\mathrm{cm} / \\
\text { day) }\end{array}$ & M.D. & $\begin{array}{l}\text { Diameter growth (cm/ } \\
\text { day) }\end{array}$ & Inhibition & M.D. & $\begin{array}{l}\text { Diameter growth }(\mathrm{cm} / \\
\text { day) }\end{array}$ & Inhibition & M.D \\
\hline $\begin{array}{l}\text { Gloelophyllum striatum } \\
\text { MCA2 }\end{array}$ & $0.69 \pm 0.08^{\mathrm{a}}$ & 2 & $0.36 \pm 0.02^{b}$ & $48 \%$ & 3 & $0.32 \pm 0.01^{b}$ & $53 \%$ & 3 \\
\hline Datronia caperata MCA5 & $0.73 \pm 0.08^{\mathrm{a}}$ & 2 & $0.24 \pm 0.02^{b}$ & $67 \%$ & 1 & $0.24 \pm 0.01^{b}$ & $67 \%$ & 1 \\
\hline Trametes modesta MCA6 & $1.07 \pm 0.16^{\mathrm{a}}$ & 2 & $0.43 \pm 0.05^{b}$ & $60 \%$ & 3 & $0.36 \pm 0.01^{b}$ & $66 \%$ & 3 \\
\hline $\begin{array}{l}\text { Gloelophyllum striatum } \\
\text { MCA7 }\end{array}$ & $0.99 \pm 0.04^{\mathrm{a}}$ & 2 & $0.38 \pm 0.02^{b}$ & $61 \%$ & 3 & $0.38 \pm 0.04^{b}$ & $61 \%$ & 3 \\
\hline Polyporus tenuiculus MCA9 & $0.42 \pm 0.01^{\mathrm{a}}$ & 3 & $0.24 \pm 0.02^{b}$ & $42 \%$ & 3 & $0.22 \pm 0.00^{b}$ & $48 \%$ & 3 \\
\hline Polyporus tenuiculus MCA11 & $0.82 \pm 0.02^{a}$ & 3 & $0.41 \pm 0.01^{b}$ & $49 \%$ & 3 & $0.32 \pm 0.01^{c}$ & $60 \%$ & 3 \\
\hline $\begin{array}{l}\text { Pycnoporus sanguineus } \\
\text { MCA16 }\end{array}$ & $1.41 \pm 0.05^{\mathrm{a}}$ & 3 & $0.45 \pm 0.04^{b}$ & $68 \%$ & 3 & $0.44 \pm 0.01^{b}$ & $69 \%$ & 3 \\
\hline Agaricales MCA17 & $0.85 \pm 0.06^{\mathrm{a}}$ & 3 & $0.40 \pm 0.04^{b}$ & $52 \%$ & 2 & $0.43 \pm 0.01^{b}$ & $49 \%$ & 2 \\
\hline Polyporus sp. MCA128 & $1.56 \pm 0.14^{a}$ & 3 & $0.44 \pm 0.09^{b}$ & $72 \%$ & 3 & $0.40 \pm 0.02^{b}$ & $74 \%$ & 3 \\
\hline Hexagonia hirta MCA131 & $2.99 \pm 0.19^{a}$ & 1 & $1.24 \pm 0.02^{b}$ & $58 \%$ & 1 & $1.16 \pm 0.05^{b}$ & $61 \%$ & 1 \\
\hline Datronia stereoides MCA167 & $1.52 \pm 0.03^{\mathrm{a}}$ & 3 & $0.41 \pm 0.02^{b}$ & $73 \%$ & 3 & $0.38 \pm 0.01^{b}$ & $75 \%$ & 3 \\
\hline Dacryopinax elegans SXS323 & $3.63 \pm 0.41^{\mathrm{a}}$ & 3 & $1.56 \pm 0.15^{b}$ & $57 \%$ & 3 & $1.60 \pm 0.21^{b}$ & $56 \%$ & 3 \\
\hline Pluteus cubensis SXS320 & $1.90 \pm 0.06^{\mathrm{a}}$ & 3 & $1.07 \pm 0.01^{b}$ & $44 \%$ & 3 & $0.73 \pm 0.01^{b}$ & $62 \%$ & 3 \\
\hline
\end{tabular}

when compared to control; this was the case of Gloellophylum striatum MCA7. Many strains also differed in pigmentation (Fig. 1).

In 20-day liquid cultures, the biomass production also decreased for the majority of strains when atrazine was present $\left(25 \mathrm{mg} \mathrm{L}^{-1}\right)$, demonstrating the toxic effects of the herbicide even in low concentrations, when compared to agar plates. Abiotic disappearance of herbicide was not detected, and among 13 isolates evaluated, 11 degraded the herbicide in levels varying from 2.9 to $38.7 \%$; it was possible to distinguish three groups of fungi regarding their competence of degrading atrazine (Table 2). Herbicide metabolites appeared in all the culture extracts in which some atrazine dissipation occurred.

The strains Gloelophyllum striatum MCA7 and Agaricales MCA17 achieved the higher biodegradation levels, 37.3 and $38.7 \%$, and their growth was not inhibited by atrazine in surface cultivation medium. Polyporus sp. MCA128, Datronia stereoides MCA167, Pluteus cubensis SXS320, and Datronia caperata MCA5, on the other side, were slightly inhibited by atrazine and had a widely variable degradation performance (Table 2).

Polyporus tenuiculus MCA11 showed the strongest laccase induction in the medium containing atrazine, and Pluteus cubensis SXS320 exhibited the best degradation rates, while no ligninolytic enzyme had been produced in any condition. Both strains were also among the ones whose growth was less inhibited in PDA (potato dextrose agar) plates (Tables 1 and 2). Therefore, more detailed studies focusing on the atrazine biodegradation and the influence of nitrogen availability on its metabolism were carried out for these two fungal isolates.

Atrazine dissipation by $P$. tenuiculus MCA11 appeared to be only the result of biomass development and cultivation time. This strain removed $39.1 \%$ of initial atrazine after 40 days in culture medium with $25 \mathrm{mM}$ of nitrogen, producing $2.24 \mathrm{~g} \mathrm{~L}^{-1}$ of biomass (data not shown); in a culture containing $2.5 \mathrm{mM}$ of $\mathrm{N}$, the degradation reached $13.9 \%$ (with $0.84 \mathrm{~g} \mathrm{~L}^{-1}$ of biomass) after 20 days of cultivation (Table 2). Atrazine sorption to the mycelium was below $3 \%$.

Pluteus cubensis SXS320, by its turn, exhibited a peculiar profile of biotransformation, closely related to nitrogen availability. A more intense degradation of atrazine was achieved by this strain in nitrogen-poor medium, reaching $30 \%$ of removal after 20 days of cultivation. Conversely, only $21 \%$ were removed after 40 days in a nitrogen-rich medium. Biomass was smaller in nitrogendeficient cultures $\left(0.943 \mathrm{~g} \mathrm{~L}^{-1}\right.$, Table 2$)$, while cultures with high nitrogen levels produced $1.6 \mathrm{~g} \mathrm{~L}^{-1}$ of mycelium on the 40th day of cultivation. Atrazine sorption to the biomass was below $5 \%$.

Both strains evaluated were able to convert atrazine it into more polar metabolites (Figs. 3 and 4 - peaks 5). The identity of the remaining metabolites, however, was directly affected by the nitrogen availability. In nitrogen rich medium, three metabolites, corresponding to the peaks with retention times of $2.98,3.6$ and $3.40 \mathrm{~min}$, 


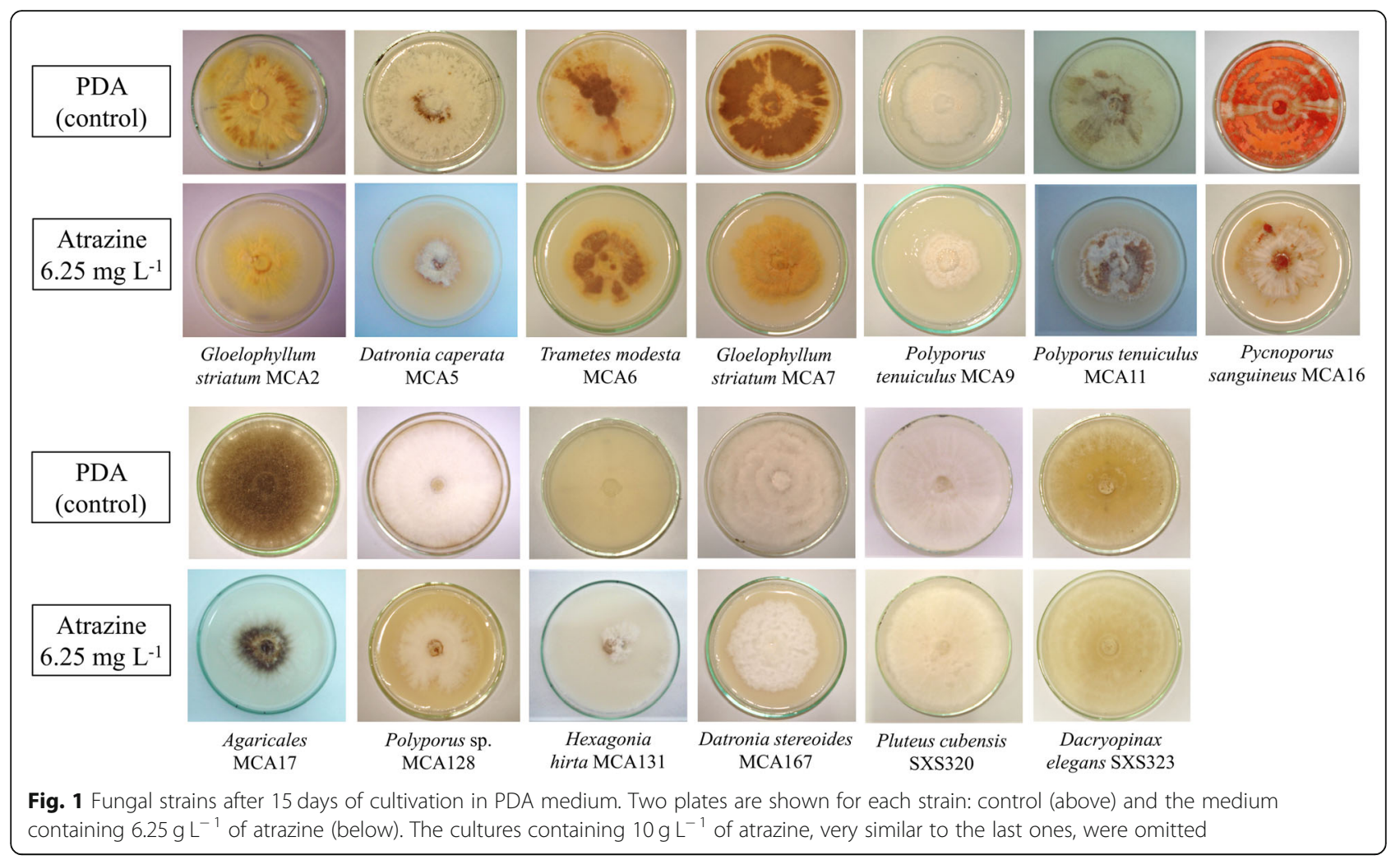

arose in the culture extracts of $P$. cubensis SXS320 within 40 days of cultivation (Fig. 2b). The chromatogram of 40-day culture of $P$. tenuiculus MCA11 had the same profile (not shown). In low-nitrogen medium, however, two different metabolites, whose peaks have retention times of 2.99 and $3.40 \mathrm{~min}$, resulted from the P. cubensis SXS320 metabolism of atrazine (Fig. 3a); P. tenuiculus MCA11, by its turn, produced only one peak (peak 5, retention time of $3.16 \mathrm{~min}$, Fig. 3b) under the same conditions.

Table 2 Fungal biomass, laccase activity and herbicide degradation after 20 days in liquid medium with $25 \mathrm{mg} \mathrm{L}^{-1}$ of initial atrazine. Superscript lowercase letters $(a-c)$ represent statistically distinct $(p \leq 0.05)$ groups

\begin{tabular}{|c|c|c|c|c|c|c|}
\hline \multirow[t]{2}{*}{ Strain } & \multicolumn{2}{|l|}{ Control } & \multicolumn{4}{|c|}{ Culture in presence of $25 \mathrm{mg} \mathrm{L}^{-1}$ of atrazine } \\
\hline & $\begin{array}{l}\text { Biomass } \\
\left(\mathrm{g} \mathrm{L}^{-1}\right)\end{array}$ & $\begin{array}{l}\mathrm{LaC} \\
\left(\mathrm{Ug}^{-1}\right)\end{array}$ & $\begin{array}{l}\text { Biomass } \\
\left(\mathrm{g} \mathrm{L}^{-1}\right)\end{array}$ & $\begin{array}{l}\text { Inhibition of } \\
\text { growth (\%) }\end{array}$ & $\begin{array}{l}\operatorname{Lac} \\
\left(\mathrm{Ug}^{-1}\right)\end{array}$ & Degradation (\%) \\
\hline Gloelophyllum striatum MCA2 & $0.93 \pm 0.01$ & - & $0.52 \pm 0.06$ & 45 & - & $0.0^{c}$ \\
\hline Datronia caperata MCA5 & $0.79 \pm 0.06$ & $25.0 \pm 8.50$ & $0.64 \pm 0.04$ & 19 & $75.7 \pm 5.39$ & $10.5^{\mathrm{bc}}$ \\
\hline Trametes modesta MCA6 & $1.70 \pm 0.16$ & - & $0.93 \pm 0.02$ & 45 & - & $14.1^{\mathrm{bc}}$ \\
\hline Gloelophyllum striatum MCA7 & $1.30 \pm 0.06$ & - & $1.377 \pm 0.08$ & 0 & - & $37.3^{\mathrm{a}}$ \\
\hline Polyporus tenuiculus MCA9 & $0.97 \pm 0.01$ & - & $0.62 \pm 0.10$ & 37 & - & $4.42^{c}$ \\
\hline Polyporus tenuiculus MCA11 & $1.71 \pm 0.47$ & $2.41 \pm 1.66$ & $0.85 \pm 0.09$ & 51 & $32.2 \pm 11.55$ & $13.9^{\mathrm{bc}}$ \\
\hline Pycnoporus sanguineus MCA16 & $1.47 \pm 0.08$ & $9.89 \pm 6.70$ & $1.01 \pm 0.11$ & 32 & $15.18 \pm 1.11$ & $11.4^{\mathrm{bc}}$ \\
\hline Agaricales MCA17 & $0.78 \pm 0.06$ & $4.03 \pm 0.91$ & $0.71 \pm 0.04$ & 0 & - & $38.7^{\mathrm{a}}$ \\
\hline Polyporus sp. MCA128 & $5.07 \pm 0.08$ & - & $4.62 \pm 0.11$ & 19 & - & $0.0^{c}$ \\
\hline Hexagonia hirta MCA131 & $2.11 \pm 0.21$ & - & $1.35 \pm 0.28$ & 36 & - & $8.6^{c}$ \\
\hline Datronia stereoides MCA167 & $5.52 \pm 0.03$ & - & $5.04 \pm 0.32$ & 18 & - & $2.9^{c}$ \\
\hline Pluteus cubensis SXS320 & $1.04 \pm 0.16$ & - & $0.94 \pm 0.05$ & 10 & - & $30.0^{\mathrm{ab}}$ \\
\hline Dacryopinax elegans SXS323 & $2.39 \pm 0.01$ & - & $1.43 \pm 0.12$ & 40 & - & $3.8^{c}$ \\
\hline $\begin{array}{l}\text { Not inoculated medium } \\
\text { (abiotic control }\end{array}$ & 0 & 0 & 0 & 0 & 0 & $0.0^{c}$ \\
\hline
\end{tabular}



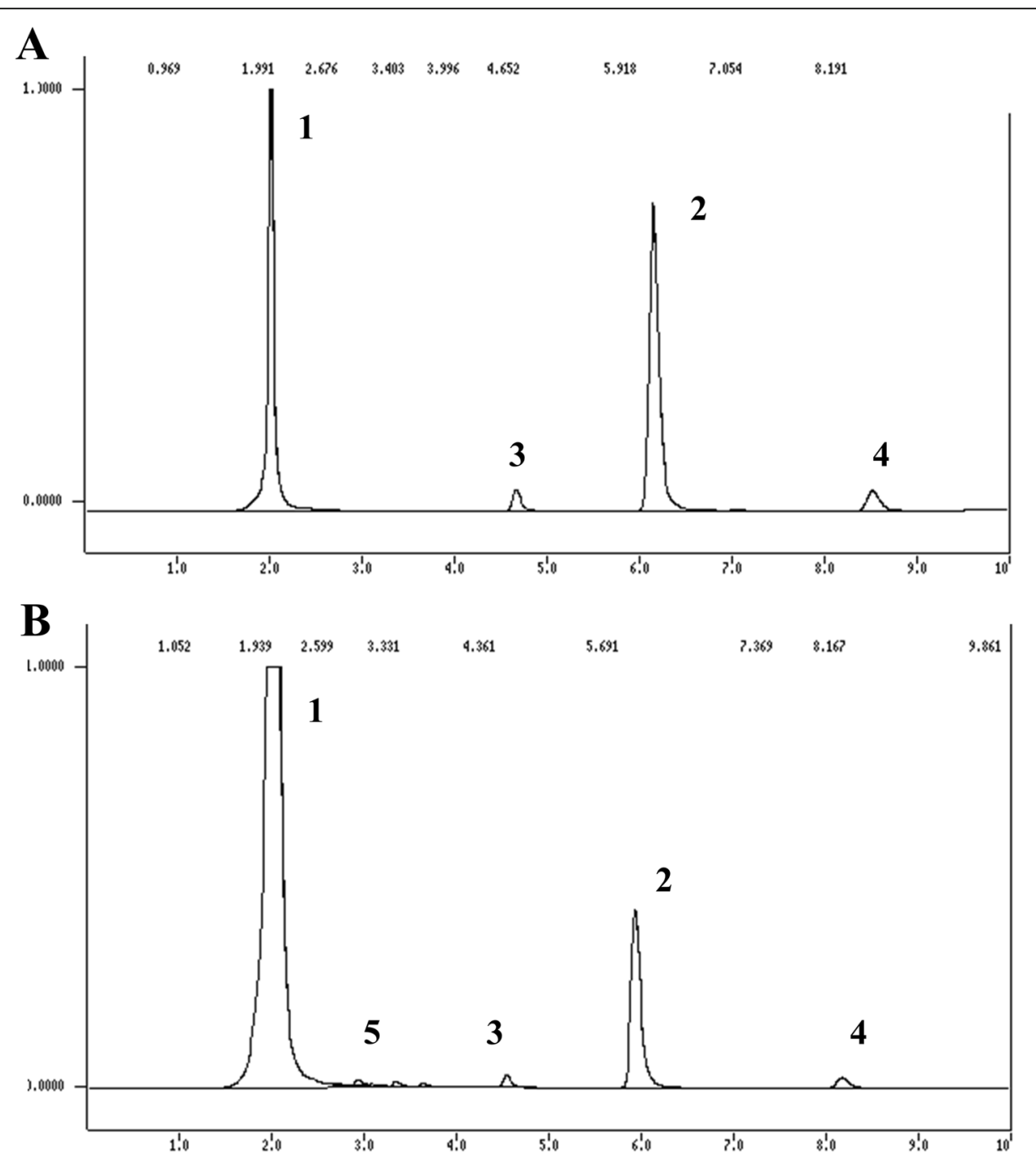

Fig. 2 Chromatograms of 40-day culture medium containing $25 \mathrm{mM}$ of $\mathrm{N}$ and initial $25 \mathrm{mg} \mathrm{L}^{-1}$ of atrazine. a abiotic medium; b: P. cubensis SXS320 culture extracts. Peak 1: non-identified compound; peak 2: atrazine; peaks 3 and 4: contaminants inherent to commercial formulation employed; peaks 5: metabolites of atrazine

To further explore the relationship among nitrogen availability, atrazine degradation and laccase biosynthesis, we cultivated P. tenuiculus MCA11 with atrazine (from 0 to $50 \mathrm{mg} \mathrm{L}^{-1}$ ), and high $\mathrm{N}$ concentration $(25$ $\mathrm{mM})$. Laccase was slightly induced by increasing atrazine levels, reaching a 4-fold activity level in medium with 50 $\mathrm{mg} \mathrm{L}^{-1}$ of the herbicide, compared to the control (Fig. 4). This induction was lower than in the medium with 2.5 $\mathrm{mM}$ of $\mathrm{N}$, where laccase levels increased 13-fold in the culture with $25 \mathrm{mg} \mathrm{L}^{-1}$ of atrazine, compared to the herbicide free culture medium (Table 2).

Laccase from $P$. tenuiculus MCA11 was the most strongly induced enzyme during this study; hence, tests to evaluate its potential to degrade the atrazine in vitro were carried out for $24 \mathrm{~h}$. Although laccase had retained $88 \%$ of initial activity after $6 \mathrm{~h}$ of incubation, no atrazine disappearance occurred (Fig. 5).

\section{Discussion}

Tolerance essays are usually the first step when screening microbial species for bioremediation, once the microorganism needs to overcome the physiological stress caused by the xenobiotic, being able to colonize the contaminated soil or substrate. Previous works reported high inhibition rates when screening fungal strains based on their capacity of growing in agar plates containing organochlorinated pesticides. Growth inhibition ranging from 3.68 to $40.1 \%$ were found among 10 white-rot fungi evaluated by Bisht et al. [25], cultured in soil extract agar containing $100 \mathrm{mg} \mathrm{L}^{-1}$ of endosulfan. Dealing with four strains of the basidiomycete genus Phlebia, Xiao \& Kondo [26] observed growth inhibition from 30 to $60.3 \%$ in PDA medium with $50 \mathrm{mg} \mathrm{L}^{-1}$ of lindane. Only Pleurotus sp. and Cymatoderma elegans, from eight basidiomycetes evaluated by Cupul et al. [10] 

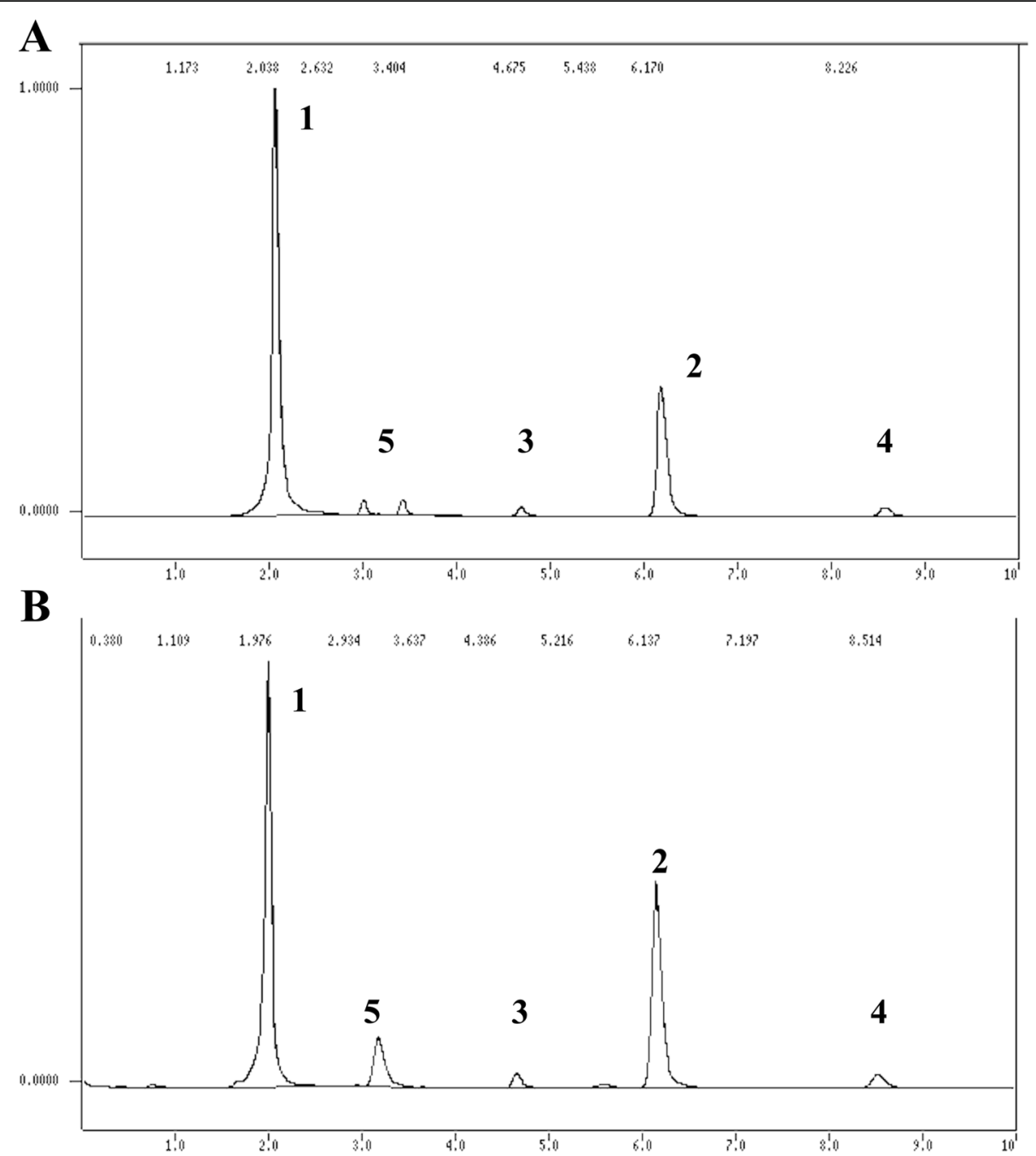

Fig. 3 Chromatogram of a 20-day culture of P. cubensis SXS320 (a) and of P. tenuiculus MCA11 (b), cultured with 2.5 mM of N. Peak 1: nonidentified compound; peak 2: atrazine; peaks 3 and 4: contaminants inherent to commercial formulation employed; peak 5: metabolites of atrazine. All cultures had initially $25 \mathrm{mg} \mathrm{L}^{-1}$ of atrazine

presented inhibition rates below $75 \%$ in plates containing $3.75 \mathrm{~g} \mathrm{~L}^{-1}$ of atrazine. Given the higher levels of atrazine evaluated here, and the comparable inhibition responses (42 to $73 \%$, in cultures containing $6.25 \mathrm{~g} \mathrm{~L}^{-1}$ of atrazine), the studied strains can be considered highly tolerant to the herbicide.

Changes in growth rates, pigmentation and spore production are common in fungi growing in toxic environments [27]. After cultivating Mucor plumbeus on pentachlorophenol contaminated medium, Carvalho et al. [28] observed an overexpression of proteins associated to increased energy demand, changes on cell wall structure and cytoskeleton, as well as responses to oxidative stress (like cytochrome c oxidase and HSP70 chaperones). The morphological changes observed here, in terms of mycelium density (Table 2) can be the result of similar biochemical disruptions.
Considering atrazine biodegradation potential by fungi, some strains of Phanerochaete and Pleurotus stand out. Phanerochaete chrysosporium removed $48 \%$ of initial atrazine from the medium within 4 days [16]. Lopes et al. [4] reported a noticeable performance of Pleurotus ostreatus INCQS 40310 degrading 82 and $56 \%$ of initial $10 \mathrm{mg} \mathrm{L}^{-1}$ of atrazine and desethylatrazine, respectively, after 15 days in liquid medium; it was the first work demonstrating the biodegradation of atrazine metabolites DIA and DEA by fungi. The proteome analysis indicated that, in this case, extracellular hydrolases and peroxidases were overexpressed in the extracellular environment. Marinho et al. [29] found that atrazine degradation by Aspergillus niger in batch reactors containing wastewater and $30 \mathrm{mg} \mathrm{L}^{-1}$ of the herbicide reached $40 \%$ after 8 days. The biodegradation rose up to $72 \%$ when the mixture was supplemented with $3 \mathrm{gL}^{-1}$ of glucose, allowing more extensive biomass development. 


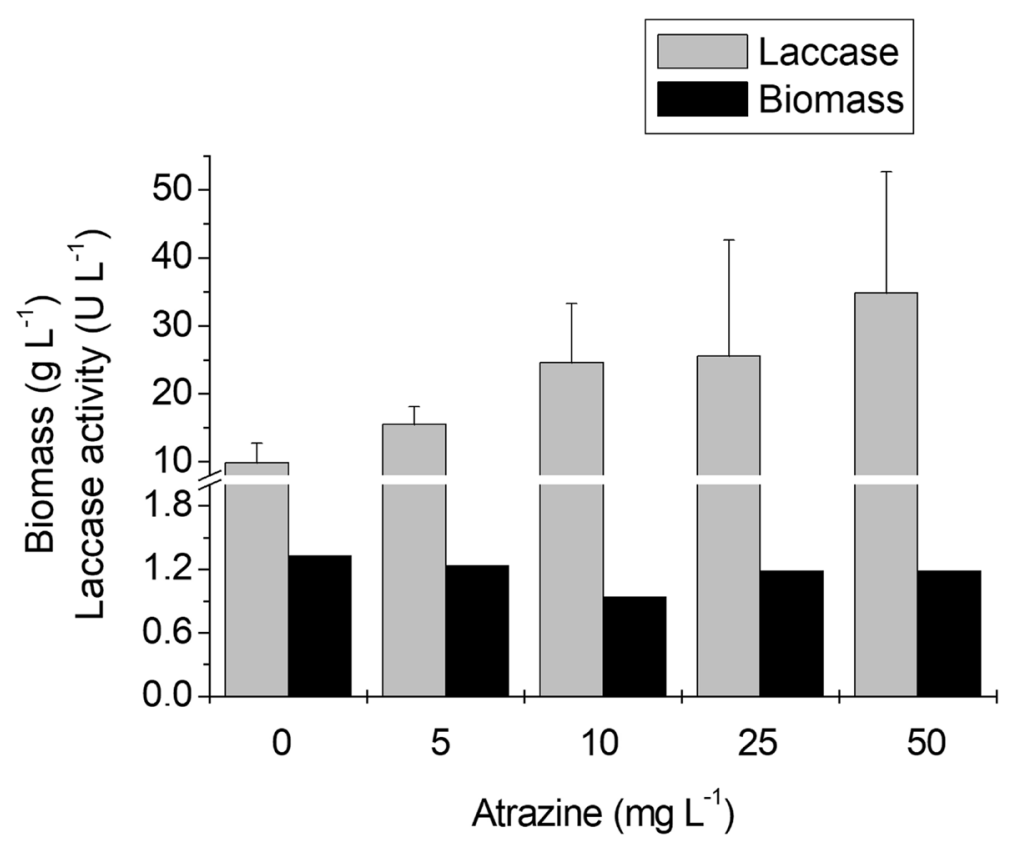

Fig. 4 Laccase production by P. tenuiculus MCA11; growth supported by $1 \%$ of glucose and $25 \mathrm{mM}$ of $\mathrm{N}$, in different atrazine concentrations

Once white-rot fungi are expected to grow better in solid substrates and soil, Anthracophyllum discolor immobilized in organic supports was capable of degrading $96 \%$ of initial atrazine in a soil matrix amended with wheat straw [20]. Considering the first results obtained in this study using liquid medium, strains like G. striatum MCA7 and Agaricales MCA17, that degraded, respectively, 37.3 and $38.7 \%$ of atrazine in liquid culture, have a great potential for extensive atrazine biodegradation in solid matrices, employing biostimulation besides a bioaugmentation strategy. Lignocellulosic crop residues, especially sugarcane bagasse, are abundant bulk agents to support fungal growth in this context.

Previous research found that atrazine degradation by Phanerochaete chrysosporium and Pleurotus ostreatus INCQS 40310 had a proportional dependence on biomass and associated enzymes $[4,15,16]$. Thus, a nutrient rich culture medium, allowing substantial biomass development,

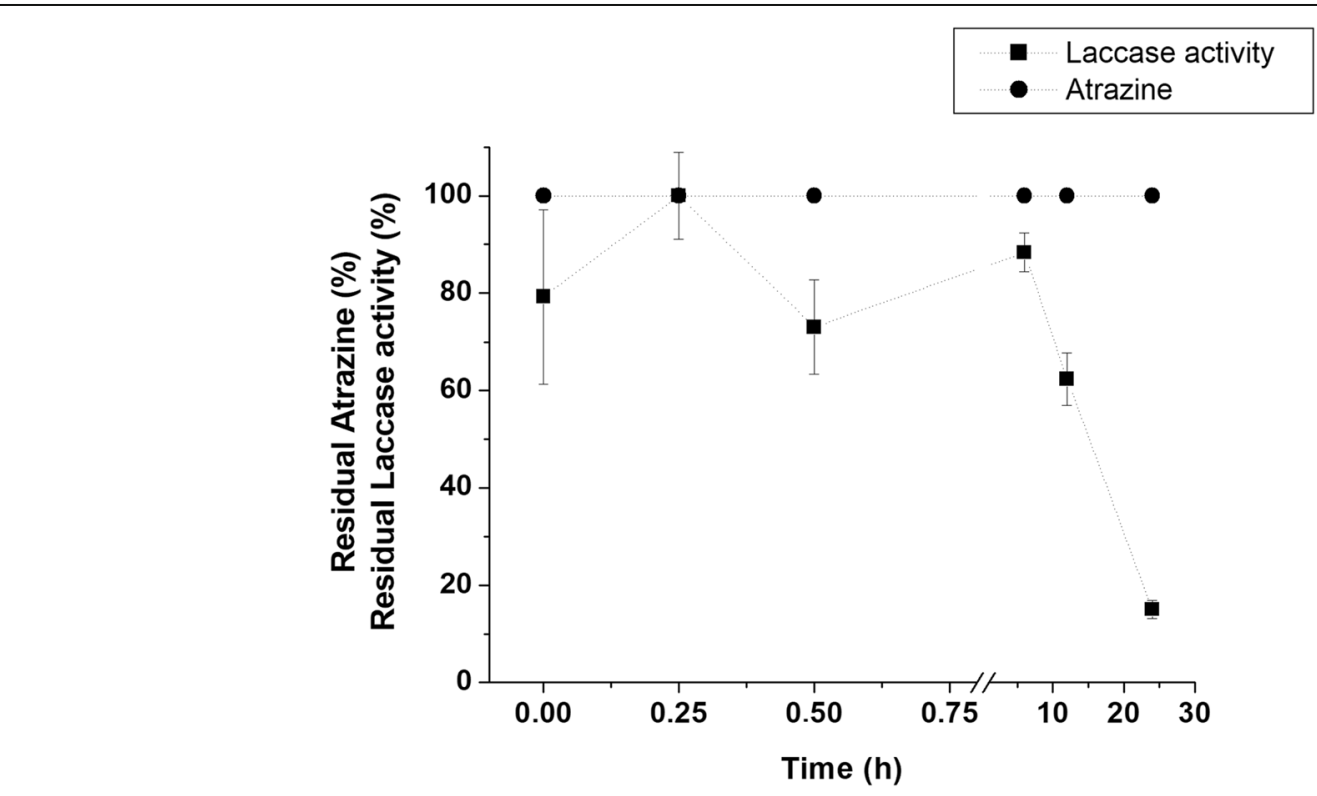

Fig. 5 Polyporus tenuiculus MCA11 laccase activity and atrazine content, during in vitro incubation 
provides best results in terms of biodegradation [22]. However, when ligninolytic system is implicated, it is often subject to catabolic repression in a nitrogen-rich culture medium [21,30]. Many evidences are in according with this; it was the case of the degradation of aldrin and dieldrin by strains of Phlebia [30], and the degradation of atrazine by Coriolus hirsutus and Cerrena maxima [31]. Tests of ligninolytic activity are often used for selecting microorganisms for bioremediation of aromatics [5]. In fact, laccases, lignin peroxidases and manganese peroxidases can co-metabolyze, in vitro and in vivo, pollutants like PAHs, polychlorinated phenols, polymers, dioxins, and pesticides [19, 32-34].

Even though $P$. cubensis SXS 320 did not produced laccases, lignin peroxidases or manganese peroxidases in any culture condition evaluated here, nitrogen availability modulated the atrazine degradation routes. One hypothesis points to the involvement of some not measured extracellular ligninolytic enzyme, like chloroperoxidase, glyoxal oxidase, tyrosinases and haem-thiolate peroxygenases [5, 35]. Even if the biodegradation depends primarily of cell-bound enzymes, they were also subject of down regulation by nitrogen, once the nitrogen-starving culture medium (that included a poor mycelium development) provided the best results.

Analyzing the behavior of the extracellular laccase produced of $P$. tenuiculus MCA 11 considering the nitrogen and atrazine levels in the culture medium, the results suggest that the biosynthesis of this enzyme is induced by atrazine, in agreement with the previous findings [36, 37]. Besides this, the enzyme is repressed by nitrogen, while herbicide degradation rates were more influenced by mycelium development than laccase levels.

The changes in the profile of the metabolites arising in low or high nitrogen culture medium support the hypothesis of different enzymes acting in each condition. Studying the gene expression of Phanerochaete chrysosporium, Kameshawar \& Qin [22] found that ligninolytic enzymes were overexpressed in a nitrogen limited medium, while cytochrome P450 enzymes, often crucial for the detoxification of xenobiotics, were mostly overexpressed in nitrogen rich cultures. This means that probably cell-bound constitutive detoxification mechanisms prevail when these strains grow in nutrient rich medium. Once under nitrogen starving, different enzymes, possibly part of the ligninolytic system, are expressed, changing the profile of metabolites [5, 22].

A recent study employing laccase from Trametes versicolor reports a poor performance in atrazine removal (less than $5 \%$ after $24 \mathrm{~h}$ ), unless a mediator is used. When $1 \mathrm{mM}$ of HBT (1-hydroxy benzotriazole) was provided, degradation rates improved by $90 \%$ [38]. Although ABTS was employed as mediator in the present study, $P$. tenuiculus MCA 11 laccase was unable to oxidize atrazine in vitro. Once ABTS and HBT are the most employed mediators to evaluate atrazine degradation by laccases, taking in account the redox potential of the chemicals involved, these results suggest that this extracellular laccase is not implicated on the atrazine biodegradation, at least on its first steps.

\section{Conclusion}

Previous studies have shown how atrazine biodegradation rates and/or ligninolytic enzymes yields depend on the nitrogen availability in culture medium; but the metabolic change induced only by the availability of this macronutrient, resulting in different biodegradation products for atrazine, was not reported until now. Besides this, the basidiomycete strains evaluated here showed a high potential for bioremediation. The identification of the metabolites resultant from fungal degradation of atrazine, while evaluating strategies to make feasible the further steps towards its complete degradation, are key aspects to ensure the security of future field applications.

\section{Methods \\ Microorganisms}

We used basidiomycete strains isolated by Santos et al. [39] and Abrahão et al. [40] from decaying wood from the Atlantic Semi-deciduous forest fragments at "Noroeste Paulista Ecological Station", Northwestern São Paulo, Brazil. Thirteen strains were chosen based on previous studies screening strains capable of growing quickly and decolorizing Remazol Brilliant Blue as an indicator of ligninolytic activity. Fungi were preserved in sterile distilled water [41] in the culture collection of the Laboratory of Biochemistry and Applied Microbiology of "Instituto de Biociências, Letras e Ciências Exatas IBILCE” from Universidade Estadual Paulista - UNESP.

\section{Fungal tolerance to atrazine}

A commercial formulation of atrazine (Nortox ${ }^{\circ} 500 \mathrm{SC}$, $50 \%$ atrazine $\mathrm{m} / \mathrm{v}$ ) was used to test fungal tolerance and biodegradation. The herbicide was added to liquid and warm potato dextrose agar (PDA) medium, to reach the mean and the higher concentrations recommended by the manufacturer for the product when ready to be applied in the soil $\left(6.25 \mathrm{~g} \mathrm{~L}^{-1}\right.$ and $\left.10.0 \mathrm{~g} \mathrm{~L}^{-1}\right)$. The medium was homogenized and placed in Petri dishes. Plates were inoculated in the center with $6 \mathrm{~mm}$ agar plugs, cut with sterile essay tubes from actively growing cultures in PDA. The cultures were maintained at $28^{\circ} \mathrm{C}$, in the dark, for 15 days. Colony diameters were measured daily, at four equidistant points, and results were expressed as percentage of inhibition related to control (PDA cultures without herbicide). Mycelium density was visually measured and categorized as high, medium, or weak. Results 
were expressed as mean of three replicates for each treatment.

\section{Inoculum for liquid cultures}

To standardize inoculum size in liquid culture experiments, a cell suspension was produced. Mycelia fragments were scraped from growing cultures in PDA medium and transferred to $250 \mathrm{ml}$ Erlenmeyer flasks containing $50 \mathrm{ml}$ of synthetic culture medium, containing per liter of distilled water: $\mathrm{KH}_{2} \mathrm{PO}_{4}, 0.2 \mathrm{~g} ; \mathrm{MgSO}_{4} \cdot 7$ $\mathrm{H}_{2} \mathrm{O}, 0.05 \mathrm{~g}$; $\mathrm{CaCl}_{2}, 0.01 \mathrm{~g}$; mineral solution, $1 \mathrm{ml}$; and vitamin solution, $0.5 \mathrm{ml}$ (to details of mineral and vitamin solution, see Kirk et al. [23]). The medium was supplemented with $1 \%$ of glucose and $\mathrm{NH}_{4} \mathrm{NO}_{3}$ to supply $25 \mathrm{mM}$ of nitrogen. After 6 days at $28^{\circ} \mathrm{C}$, cultures were drained; mycelium was washed twice with sterile Knapp buffer [42] and ground on a stainless steel sterile mixer with the buffer. The resultant cell suspension was diluted in buffer to reach an optical density of 0.5 at 550 $\mathrm{nm}$ (DU Spectrophotometer, Beckmann), and then used immediately to inoculate test cultures (Fig. 6).

\section{Atrazine degradation and enzyme production}

An atrazine stock solution was prepared by homogenizing the commercial formulation in methanol, followed by two sonication pulses of $15 \mathrm{~min}$ and centrifugation at $10,000 \mathrm{~g}$ for $10 \mathrm{~min}$. Supernatant was filtered through a Millipore membrane of $0.2 \mu \mathrm{m}$ pore size. Aliquots were dispensed into sterile $125 \mathrm{ml}$ Erlenmeyer flasks to reach final concentrations of 0 to $50 \mathrm{mg} \mathrm{L}^{-1}$. After $24 \mathrm{~h}$, checking for the complete methanol evaporation, $25 \mathrm{ml}$ of sterile culture medium described above were added. The medium was supplemented with $1 \%$ glucose and $\mathrm{NH}_{4} \mathrm{NO}_{3}$ (to reach $2.5 \mathrm{mM}$ of $\mathrm{N}$ for a nitrogen-deficient medium). Each flask was inoculated with $1 \mathrm{ml}$ of the cell suspension. Cultures were vacuum filtered after incubation for 20 days, under static conditions at $28^{\circ} \mathrm{C}$. The supernatant, referred as crude extracts, were kept in an ice bath for enzyme assays, and aliquots were frozen. Mycelia were dried at $70^{\circ} \mathrm{C}$ to evaluate biomass and fragments were reserved to measure fungal atrazine sorption. Sterile controls were included. Results are express as mean of three replicates under each condition [43].

Aiming to evaluate the influence of nitrogen upon atrazine degradation, the strains Polyporus tenuiculus MCA11 and Pluteus cubensis SXS320 were cultivated as described above, supplementing the culture medium with $25 \mathrm{mM}$ of $\mathrm{N}$ (nitrogen sufficiency condition). Enzymatic essays were done after 8, 24, 16, 32 and 40 days of cultivation. Biomass and atrazine degradation were evaluated at the end of cultivation time.

\section{Atrazine biotransformation analysis by high performance liquid chromatography (HPLC)}

Frozen samples from cultures were melted, centrifuged at $10,000 \mathrm{~g}$ for $10 \mathrm{~min}$ and filtered in a $0.22 \mu \mathrm{m}$ pore size

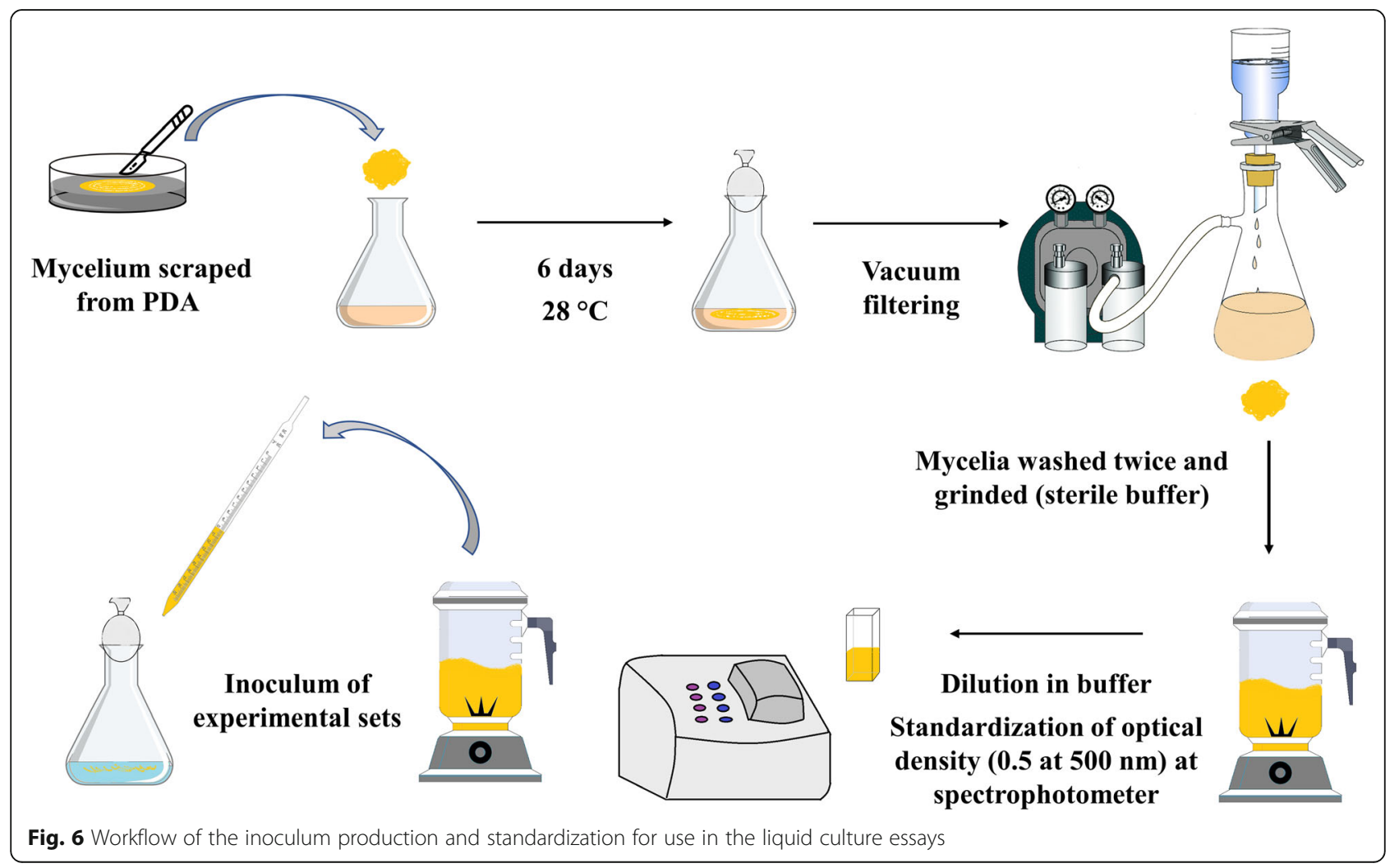


filter. Then, $20 \mu \mathrm{L}$ of each sample were injected into a Jasco HPLC, by using a C18 Perkin Elmer column contained in an oven at $40{ }^{\circ} \mathrm{C}$. Pesticides and metabolites were eluted by using a mobile phase of acetonitrile:water $(55 / 45 \mathrm{v} / \mathrm{v})$ with a flow rate of $1 \mathrm{ml} \mathrm{min}^{-1}$, and detected by UV absorbance at $220 \mathrm{~nm}$. Analytical standard was purchased from Sigma (atrazine, 98\% of purity). Quality control of the HPLC data was based on the standard curve for concentrations between 1 up to $50 \mathrm{mg} \mathrm{L}^{-1}$ $\left(R^{2}=0.992\right)$. The recovery index $(99 \%)$ was based on the detected atrazine amounts after diluting known amounts of the herbicide in the culture medium employed in the essays. To evaluate sorption of atrazine to fungal mycelium, the biomass (approximately $150 \mathrm{mg}$ ) was ground in a mortar and extracted twice with $500 \mu \mathrm{L}$ of n-hexane. Extracts were combined and air dried. The residue was re-suspended into $1 \mathrm{ml}$ of mobile phase, filtered through $0.22 \mu \mathrm{m}$ pore filter, and analyzed in chromatograph (adapted from Vroumsia et al. [44]).

\section{Enzyme assays}

Laccase activity was measured throughout the reaction using $0.9 \mathrm{ml}$ of sodium acetate buffer $(10 \mathrm{mM}$, pH 3.5) with 0.03\% of ABTS - 2,2' -azino-bis (3-ethylbenzothiazoline-6sulfonic acid) diammonium salt (Fluka, Switzerland), and $0.1 \mathrm{ml}$ of diluted enzyme crude extract [38]. After incubation for $1 \mathrm{~min}$ at $40^{\circ} \mathrm{C}$, the absorbance was read at $420 \mathrm{~nm}$ [21]. For the reaction blanks, water replaced enzyme extract. Reaction mixtures of controls lacked ABTS. One unit of activity represents the amount of enzyme that oxidizes $1 \mu \mathrm{mol}$ of ABTS per minute, considering $\varepsilon_{420}=$ of $3,6.10^{4}$ $\mathrm{M}^{-1} \mathrm{~cm}^{-1}$ for oxidized ABTS. The activity was expressed as $\mathrm{U} \mathrm{g}^{-1}$ of dry biomass.

Analysis for manganese-dependent peroxidases were carried out by adding $0.1 \mathrm{ml}$ of crude enzyme extract into a mixture containing $0.8 \mathrm{ml}$ of sodium lactate buffer $(50 \mathrm{mM}$, $\mathrm{pH} 4.5), 0.1 \mathrm{ml}$ of $\mathrm{MnSO}_{4}$ solution $(400 \mathrm{mM})$ and $4 \mu \mathrm{L}$ of a $10 \mathrm{mM} \mathrm{H} \mathrm{H}_{2} \mathrm{O}_{2}$ solution. After $10 \mathrm{~min}$ incubated at $40{ }^{\circ} \mathrm{C}$, readings were made at $240 \mathrm{~nm}$ [45]. In the blanks, enzyme was replaced by distilled water, while controls lacked $\mathrm{MnSO}_{4}$. One unit of enzyme activity represented the enzyme necessary to create $1 \mu \mathrm{mol}$ of complexes lactate- $\mathrm{Mn}^{3+}$ per minute, considering $\varepsilon_{240}=8,1 \cdot 10^{3} \mathrm{M}^{-1} \mathrm{~cm}^{-1}$ [46].

Reaction for lignin peroxidases was based on the oxidization of veratryl alcohol into veratraldehyde. Enzymatic extract was added to a mixture containing $0.8 \mathrm{ml}$ of sodium tartarate buffer ( $\mathrm{pH} 3.0,50 \mathrm{mM}), 0.1 \mathrm{ml}$ of a 40 $\mathrm{mM}$ veratryl alcohol (Fluka, Switzerland), and $4 \mu \mathrm{L}$ of $100 \mathrm{mM} \mathrm{H} \mathrm{O}_{2}$ [47]. After $10 \mathrm{~min}$ at $40^{\circ} \mathrm{C}$, absorbance was read at $310 \mathrm{~nm}$. In the blanks, distilled water replaced the enzyme; in controls, veratryl alcohol was replaced by water. One unit of enzyme activity represents the amount of enzyme that oxidizes $1 \mu \mathrm{mol}$ of veratraldehyde per minute, using $\varepsilon_{310 \mathrm{~nm}}=9.10^{3} \mathrm{M}^{-1} \mathrm{~cm}^{-1}$.

\section{Effects of laccase upon atrazine in vitro}

A reaction mixture containing $0.8 \mathrm{ml}$ of a $25 \mathrm{mg} \mathrm{L}^{-1}$ atrazine solution, $0.1 \mathrm{ml}$ of a $500 \mathrm{mM}$ sodium acetate buffer (pH 2.5) with $0.03 \%$ of ABTS and $0.1 \mathrm{ml}$ of $P$. tenuiculus MCA11 enzyme crude extract was incubated at $40{ }^{\circ} \mathrm{C}$ for $24 \mathrm{~h}$ (optimal $\mathrm{pH}$ and temperature for laccase activity were determined in previous essays). Periodically, aliquots were taken and immediately frozen in liquid nitrogen. For the analysis of atrazine content, melted samples were filtered through a $0.22 \mu \mathrm{m}$ membrane and evaluated by HPLC. Reactions employing $\mathrm{pH}$ 7.0 (Mcllvaine buffer) or omitting ABTS, enzyme or atrazine were included as controls [19].

\section{Data analysis}

One-way ANOVA (analysis of variance), followed by Tukey post-hoc tests, was used to test the influence of atrazine upon fungal growth and enzyme production, as well as atrazine biodegradation rates. Normality and homoscedasticity were tested using Shapiro-Wilk and Levene's test, respectively. Analyses were conducted in the software R Studio version 3.5.1 (R Core Team [48]).

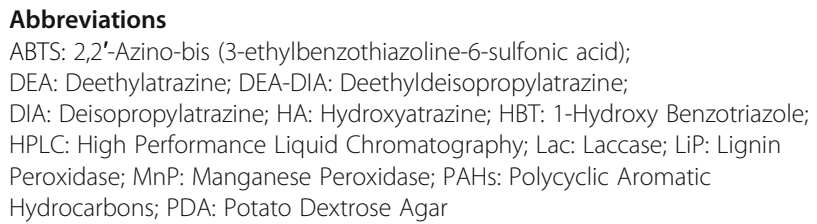

\section{Acknowledgements}

Authors are grateful to Maira C. Abrahão for the fungal strains employed. Diogo Borges Provete reviewed the English language.

\section{Authors' contributions}

C.H. performed the laboratory assays and was a major contributor in writing the manuscript. D.A.M. was responsible by the chromatographic analysis. M. B., R. S. and E. G. oriented he general work and reviewed the manuscript. All authors declare to have read and approved the manuscript.

\section{Funding}

This study was funded by FAPESP - Fundação de Amparo à Pesquisa do Estado de São Paulo (Grant N. ${ }^{\circ} 06$ /05411-5) and Conselho Nacional de Desenvolvimento Científico e Tecnológico (CNPq).

Funding bodies had no roles in study design, collection, analysis, and interpretation of data, or preparation of the manuscript.

Availability of data and materials

The datasets analyzed during the current study are available upon request to the corresponding author.

Ethics approval and consent to participate

This article does not contain any studies with human participants or animals performed by any of the authors.

Consent for publication

Not applicable.

Competing interests

The authors declare that they have no competing interests. 


\section{Author details}

${ }^{1}$ ITAIPU Binacional, Divisão de Reservatório, Avenida Tancredo Neves, 6731 Foz do Iguaçu, PR 85866-900, Brasil. 'Laboratório de Bioquímica e Microbiologia Aplicada, Instituto de Biociências, Letras e Ciências Exatas, Universidade Estadual Paulista, UNESP, São José do Rio Preto, SP, Brasil.

Received: 25 March 2020 Accepted: 18 August 2020

Published online: 26 August 2020

\section{References}

1. Karlsson AS, Weihermüller L, Tappe W, Mukherjee S, Spielvogel S. Field scale boscalid residues and dissipation half-life estimation in a sandy soil. Chemosphere. 2016. https://doi.org/10.1016/j.chemosphere.2015.11.026.

2. Kolekar PD, Patil SM, Suryavanshi MV, Suryawanshi SS, Khandare RV, et al. Microcosm study of atrazine bioremediation by indigenous microorganisms and cytotoxicity of biodegraded metabolites. J Hazard Mater. 2019. https:// doi.org/10.1016/j.jhazmat.2019.01.023.

3. Singh S, Kumar V, Chauhn A, Datta S, Wani AB, Singh N, et al. Toxicity, degradation and analysis of the herbicide atrazine. Environ Chem Lett. 2018. https://doi.org/10.1080/03601230701735227.

4. Lopes RDO, Pereira PM, Pereira ARB, Fernandes KV, Carvalho JF, França ADSD, et al. Atrazine, desethylatrazine (DEA) and desisopropylatrazine (DIA) degradation by Pleurotus ostreatus INCQS 40310. Biocatal Biotransformation. 2020. https://doi.org/10.1080/10242422.2020.1754805

5. Harms H, Schlosser D, Wick LY. Untapped potential: exploiting fungi in bioremediation of hazardous chemicals. Nat Rev Microbiol. 2011. https://doi. org/10.1038/nrmicro2519.

6. Serbent MP, Guimarães DKS, Drechsler-Santos ER, Helm CV, Giongo A Tavares LBB. Growth, enzymatic production and morphology of the whiterot fungi Lentinus crinitus (L.) Fr. Upon 2,4-D herbicide exposition. Int J environ Sci Technol. 2020. 2020. https://doi.org/10.1007/s13762-020-02693-1.

7. Moody SC, Dudley E, Hiscox J, Boddy L, Eastwood DC. Interdependence of primary metabolism and xenobiotic mitigation characterizes the proteome of Bjerkandera adusta during wood decomposition. Appl Environ Microbiol. 2018. https://doi.org/10.1128/AEM.01401-17.

8. ljoma GN, Tekere M. Potential microbial applications of co-cultures involving ligninolytic fungi in the bioremediation of recalcitrant xenobiotic compounds. Int J Environ Sci Technol. 2017. https://doi.org/10.1007/s13762017-1269-3.

9. Cameron MD, Timofeevski S, Aust SD. Enzimology of Phanerochaete chrysosporium with respect to the degradation of recalcitrant compounds and xenobiotics. Appl Microbiol Biotechnol. 2000. https://doi.org/10.1007/ s002530000459.

10. Cupul WC, Abarca GH, Vázquez RR, Salmones D, Hernández RG, Gutiérrez EA. Response of ligninolytic macrofungi to the herbicide atrazine: doseresponse bioassays. Rev Argent Microbiol. 2014. https://doi.org/10.1016/ S0325-7541(14)70094-X.

11. Gomes E, Aguiar AP, Carvalho CC, Bonfá MRL, Da Silva R, Boscolo M Ligninases production by basidiomycetes strains on lignocellulosic agricultural residues and their application in the decolorization of synthetic dyes. Braz J Microbiol. 2009. https://doi.org/10.1590/S151783822009000100005

12. Pereira PM, Teixeira RSS, Oliveira MAL, Silva M, Ferreira-Leitão VS. Optimized atrazine degradation by Pleurotus ostreatus INCQS 40310: an alternative for impact reduction of herbicides used in sugarcane crops. J Microb Biochem Technol. 2013. https://doi.org/10.4172/1948-5948.S12-006.

13. Rabinovich ML, Bolobova AV, Vasil'chenko LG. Fungal decomposition of natural aromatic structures and xenobiotics: a review. Appl Biochem Microbiol. 2004. https://doi.org/10.1023/B:ABIM.0000010343.73266.08

14. Fan X, Song F. Bioremediation of atrazine: recent advances and promises. J Soils Sediments. 2014. https://doi.org/10.1007/s11368-014-0921-5.

15. Mougin C, Laugero C, Asther M, Chaplain V. Biotransformation of s-triazine herbicides and related degradation products in liquid cultures by the whiterot fungus Phanerochaete chrysosporium. Pestic Sci. 1997. https://doi.org/10. 1002/(SICI)1096-9063(199702)49:2<169::AID-PS520>3.0.CO;2-0.

16. Mougin C, Laugero C, Asther M, Dobroca J, Frasse P, Asther M. Biotransformation of the herbicide atrazine by the white-rot fungus Phanerochaete chrysosporium. Appl Environ Microbiol. 1994;60:705-8.

17. Masaphy $S$, Levanon D, Henis $Y$. Degradation of atrazine by the lignocellulolytic fungus Pleurotus pulmonarius during solid-state fermentation. Bioresour Technol. 1996. https://doi.org/10.1016/09608524(96)00026-0.

18. Chan-Cupul W, Heredia-Abarca G, Rodríguez R. Atrazine degradation by fungal co-culture enzyme extracts under different soil conditions. J Environ Sci Health B. 2016. https://doi.org/10.1080/03601234.2015.1128742.

19. Jin X, Yu X, Zhu G, Zheng Z, Feng F, Zhang Z. Conditions optimizing and application of laccase-mediator system (LMS) for the laccase-catalyzed pesticide degradation. Sci Rep. 2016. https://doi.org/10.1038/srep35787.

20. Elgueta S, Santos C, Lima N, Diez MC. Atrazine dissipation in a biobed system inoculated with immobilized white-rot fungi. Arch Agron Soil Sci. 2016. https://doi.org/10.1080/03650340.2016.1155699.

21. Buswell JA, Cai Y, Chang S. Effect of nutrient nitrogen and manganese on manganese peroxidase and laccase production by Lentinula (Lentinus) edodes. FEMS Microbiol Lett. 1995. https://doi.org/10.1111/j.1574-6968.1995. tb07504.x.

22. Kameshwar AKS, Qin W. Gene expression metadata analysis reveals molecular mechanismsemployed by Phanerochaete chrysosporium during lignin degradation and detoxification of plant extractives. Curr Genet. 2017. https://doi.org/10.1007/s00294-017-0686-7.

23. Kirk TK, Schultz E, Connors WJ, Lorenz LF, Zeikus JG. Influence of culture parameters on lignin metabolism by Phanerochaete chrysosporium. Arch Microbiol. 1978. https://doi.org/10.1007/BF00738547.

24. Hawksworth DL, Lücking R. Fungal diversity revisited: 2.2 to 3.8 million species. In: Heitman J, Howlett BJ, Crous PW, Stukenbrock EH, James TY, Gow NAR, editors. The fungal kingdom. Washington: ASM Press; 2018. p. 79-95.

25. Bisht J, Harsh NSK, Palni LMS, Agnihotri V, Kumar A. Biodegradation of chlorinated organic pesticids endosulfan and chlorpyrifos in soil extract broth using fungi. Remediation. 2019. https://doi.org/10.1002/rem.21599.

26. Xiao P, Kondo R. Potency of Phlebia species of white rot fungi for the aerobic degradation, transformation and mineralization of lindane. J Microbiol. 2020. https://doi.org/10.1007/s12275-020-9492-x.

27. Périgon S, Massier M, Germain J, Binet MN, Legay N, Mouhamadou B. Metabolic adaptation of fungal strains in response to contamination by polychlorinated biphenyls. Environ Sci Pol Res. 2019. https://doi.org/10.1007/ s11356-019-04701-5.

28. Carvalho MB, Martins I, Medeiros J, Tavares S, Planchon S, Ranaut J, et al. The response of Mucor plumbeus to pentachlorophenol: a toxicoproteomics study. J Proteome. 2015. https://doi.org/10.1016/j.jprot.2012.11.006.

29. Marinho G, Barbosa BCA, Rodrigues K, Aquino M, Pereira L. Potential of the filamentous fungus Aspergilus niger AN400 to degrade atrazine in wastewaters. Biocatal Agric Biotechnol. 2017. https://doi.org/10.1016/j.bcab. 2016.12.013.

30. Xiao P, Mori P, Kamei I, Kiyota H, Takagi K, Kondo R. Novel metabolic pathways of organochlorine pesticides dieldrin and aldrin by the white rot fungi of the genus Phlebia. Chemosphere. 2011. https://doi.org/10.1016/j. chemosphere.2011.06.028.

31. Gorbatova ON, Koroleva OV, Lanesman EO, Stepanova EV, Zherdev AV. Increase of detoxification potential of basidiomycetes by induction of laccase biosynthesis. Appl Biochem Microbiol. 2006. https://doi.org/10.1134/ S0003683806040132.

32. Lee H, Jang Y, Choi YS, Kim MJ, Lee J, Lee H, et al. Biotechnological procedures to select white rot fungi for the degradation of PAHs. J Microbiol Methods. 2014. https://doi.org/10.1016/j.mimet.2013.12.007.

33. Tsujiyama S, Muraoka T, Takada N. Biodegradation of 2,4-dichlorophenol by shiitake mushroom (Lentinula edodes) using vanillin as an activator. Biotechnol Lett. 2013. https://doi.org/10.1007/s10529-013-1179-5.

34. Yadav M, Yadav HS. Applications of ligninolytic enzymes to pollutants, wastewater, dyes, soil, coal, paper and polymers. Environ Chem Lett. 2015. https://doi.org/10.1007/s10311-015-0516-4.

35. Furukawa T, Bello FO, Horsfall L. Microbial enzyme systems for lignin degradation and their transcriptional regulation. Front Biol. 2014. https://doi. org/10.1007/s11515-014-1336-9.

36. Song F, Li J, Fan X, Zhang Q, Chang W, Yang F, et al. Transcriptome analysis of Glomus mossae/Medicago sativa mycorrhiza on atrazine stress. Sci Rep. 2016. https://doi.org/10.1038/srep20245.

37. Sui X, Wu Q, Chang W, Fan X, Song F. Proteomic analysis of the response of Funnelifor mismosseae/Medicago sativa to atrazine stress. BMC Plant Biol. 2018. https://doi.org/10.1186/s12870-018-1492-1.

38. Nguyen LN, Hai FI, Yang S, Kang J, Leusch FDL, Roddick F, et al. Removal of pharmaceuticals, steroid hormones, phytoestrogens, UV-filters, industrial 
chemicals and pesticides by Trametes versicolor: role of biosorption and biodegradation. Int Biodeterior Biodeg. 2013. https://doi.org/10.1016/j.ibiod. 2013.12.017.

39. Santos SX, Carvalho CC, Bonfá MRL, Da Silva R, Gomes E. Screening for pectinolytic activity of wood-rotting Basidiomycetes and characterization of the enzymes. Folia Microbiol. 2004. https://doi.org/10.1007/BF02931645.

40. Abrahão MC, Gugliotta AM, Da Silva R, Fujieda RJY, Boscolo M, Gomes E. Ligninolytic activity from newly isolated basidiomycete strains and effect of these enzymes on the azo dye orange II decolourisation. Ann Microbiol. 2008. https://doi.org/10.1007/BF03175538.

41. Castellani A. The "water cultivation" of pathogenic fungi. Ann Soc Belg Med Trop. 1969;44:217-20.

42. Tixier C, Bogaerts P, Sancelme M, Bonnemoy F, Twagilimana L, Cuer A, et al. Fungal biodegradation of a phenylurea herbicide, diurom: structure and toxicity of metabolite. Pest Manag Sci. 2000. https://doi.org/10.1002/ (SICI) 1526-4998(200005)56:5<455::AID-PS152>3.0.CO;2-Z.

43. Coelho JS, Oliveira AL, Souza CGM, Bracht A, Peralta RM. Effect of the herbicides bentazon and diuron on the production of ligninolytic enzymes by Ganoderma lucidum. Int Biodeterior Biodegradation. 2010. https://doi. org/10.1016/j.jbiod.2009.12.006

44. Vroumsia T, Steiman R, Seigle-Murandi F, Benoit-Guyod JL, Khadrani A. Biodegradation of three substituted phenylurea herbicides (chlortoluron, diuron, and isoproturon) by soil fungi. A comparative study. Chemosphere. 1996. https://doi.org/10.1016/0045-6535(96)00318-9.

45. Gianfreda L, Mora ML, Diez MC. Restoration of polluted soils by means of microbial and enzymatic processes. R C Suelo Nutric Veg. 2006. https://doi. org/10.4067/s0718-27912006000100004.

46. Aitken MD, Irvine LR. Characterization of reactions catalyzed by manganese peroxidase from Phanerochaete chrysosporium. Arch Biochem Biophys. 1990. https://doi.org/10.1016/0003-9861(90)90739-L.

47. Tien M, Kirk TK. Lignin peroxidase of Phanerochaete chrysosporium. Methods Enzymol. 1988. https://doi.org/10.1016/0076-6879(88)61025-1.

48. R Core Team: R: A language and environment for statistical computing. 2013. http://www.R-project.org. Accessed in 05 May 2020.

\section{Publisher's Note}

Springer Nature remains neutral with regard to jurisdictional claims in published maps and institutional affiliations.

Ready to submit your research? Choose BMC and benefit from:

- fast, convenient online submission

- thorough peer review by experienced researchers in your field

- rapid publication on acceptance

- support for research data, including large and complex data types

- gold Open Access which fosters wider collaboration and increased citations

- maximum visibility for your research: over $100 \mathrm{M}$ website views per year

At $\mathrm{BMC}$, research is always in progress.

Learn more biomedcentral.com/submissions 